\title{
Evidence that Fgf10 offers therapeutic opportunities after hyperoxic lung injury in mice
}

\author{
CM Chao ${ }^{1,3^{*}}$, D Al Alam², S Schermuly ${ }^{3}$, H Ehrhardt $^{1}$, KP Zimmer ${ }^{1}$, S Bellusci ${ }^{3}$ \\ From 50th Workshop for Pediatric Research \\ Gottingen, Germany. 20-21 March 2014
}

Bronchopulmonary dysplasia (BPD), a chronic lung disease of preterm infants, is characterized by impaired alveolar growth and pathologic vascularization.

\section{Aims}

To investigate the role of $F g f 10$ in alveologenesis and during/after hyperoxic lung injury.

\section{Methods}

1) 10 weeks old $\mathrm{Fgf10} \mathrm{O}^{+/}$mice (50\% Fgf10 expression compared to WT) in normoxic condition: Lung function and morphometric analysis.

2) BPD model:

a) $\mathrm{FgflO}^{+/-}$and $\mathrm{Fgf10^{+/+ }}$ mice were exposed to $85 \% \mathrm{O}_{2}$ from P0-P8. Morphometric analysis and $\alpha$-Actin/vWF staining were performed at $\mathrm{P} 3$.

b) Rosa26 $6^{r T A /+} ;$ tet $(O) F g f 10$ (gain-of-function) mice were exposed to $85 \% \mathrm{O}_{2}$ from P0-P8. From P9-P45 the pups were exposed to normoxia and fed either with normal food (control) or doxycycline food (experimental) to activate the transgene Fgf10. Morphometric analysis was carried out at P45.

3) Tolerance study: Rosa2 ${ }^{r t T A /+}$;tet(O)Fgf10 and WT mice (both 10 weeks old) were exposed to doxycycline for 2 weeks. Then survival rate, histology, Ki67 and TUNEL staining were performed.

\section{Results}

1) $\mathrm{Fg} 1 \mathrm{O}^{+/-}$mice under normoxic condition have worse lung function and lung structure compared to WT mice.

2) All $\mathrm{Fgf10^{+/- }}$ mice die from hyperoxic injury due to increased lung injury and vascular malformation.

3) Overexpression of $F g f 10$ after hyperoxic injury leads to improvement of lung structure compared to control group without overexpression.

1Justus-Liebig-Universität, Gießen, Germany

Full list of author information is available at the end of the article
4) Fgf10 overexpression after hyperoxic injury does not increase mortality and side effects (weight loss, mucosal proliferation due to hypercellularity with no impact on apoptosis) are reversible.

\section{Conclusion}

Fgf10 attenuates hyperoxic lung injury, is well tolerated and should be further studied as a potential therapeutic for BPD.

\section{Authors' details}

${ }^{1}$ Justus-Liebig-Universität, Gießen, Germany. ${ }^{2}$ Saban Research Institute, Los Angeles, USA. ${ }^{3}$ Excellence Cluster Cardio-Pulmonary System, Gießen, Germany.

Published: 11 September 2014

doi:10.1186/2194-7791-1-S1-A27

Cite this article as: Chao et al:: Evidence that Fgf10 offers therapeutic opportunities after hyperoxic lung injury in mice. Molecular and Cellular Pediatrics 2014 1(Suppl 1):A27.

Submit your manuscript to a SpringerOpen ${ }^{\bullet}$ journal and benefit from:

- Convenient online submission

- Rigorous peer review

- Immediate publication on acceptance

- Open access: articles freely available online

- High visibility within the field

- Retaining the copyright to your article

Submit your next manuscript at $>$ springeropen.com
(C) 2014 Chao et al; licensee Springer This is an Open Access article distributed under the terms of the Creative Commons Attribution License (http://creativecommons.org/licenses/by/2.0), which permits unrestricted use, distribution, and reproduction in any medium, provided the original work is properly cited. 